Relations industrielles

Industrial Relations

\title{
Labour Arbitration Procedures. By C. H. Curtis. Kingston. Ont.: Department of Industrial Relations, Queen's University, 1957, pp. 90 .
}

\section{Roger Chartier}

Volume 12, numéro 4, octobre 1957

URI : https://id.erudit.org/iderudit/1022525ar

DOI : https://doi.org/10.7202/1022525ar

Aller au sommaire du numéro

Éditeur(s)

Département des relations industrielles de l’Université Laval

ISSN

0034-379X (imprimé)

1703-8138 (numérique)

Découvrir la revue

Citer ce compte rendu

Chartier, R. (1957). Compte rendu de [Labour Arbitration Procedures. By C. H. Curtis. Kingston. Ont.: Department of Industrial Relations, Queen's University, 1957, pp. 90.] Relations industrielles / Industrial Relations, 12(4), 410-410.

https://doi.org/10.7202/1022525ar

Tous droits réservés (C Département des relations industrielles de l’Université Laval, 1957
Ce document est protégé par la loi sur le droit d'auteur. L’utilisation des services d'Érudit (y compris la reproduction) est assujettie à sa politique d'utilisation que vous pouvez consulter en ligne.

https://apropos.erudit.org/fr/usagers/politique-dutilisation/ 
Après avoir exposé la situation au double point de vue législatif et syndical avant la naissance de la CTCC, l'auteur étudie le rôle qu'a joué ce groupement dans l'élaboration de la Loi des syndicats professionnels (1924), la Loi de la convention collective (1934) et la Loi des relations ouvrières (1944).

Le texte original de l'auteur remonte à 1948 et a fait l'objet d'une dissertatilon soumise à la Faculté des sciences sociales, économiques et politiques de l'Université de Montréal pour l'obtention d'une maîtrise en relations industrielles.

Cette étude ne manque pas d'intérêt parce qu'en notre province les travaux du genre sont rares, sinon inexistants. Toutefois. l'auteur lui-même admettra que certains jugements qu'il a portés à l'époque mériteraient d'être nuancés et surtout que son travail a besoin d'être complété et mis à date. Nous ne doutons pas que. revenu à l'enseignement universitaire depuis cette année, il se chargera de le faire pour le bénéfice de tous ceux qu'intéressent les relations du travail en notre province.

Cette nouvelle collection de l'Institut social populaire est appelée à combler une grande lacune dans notre littérature des relations du travail. Avec ce premier cahier, elle ouvre de riches perspectives et mérite d'être encouragée.

G. D.
Labour Arbitration Procedures. By C. H. Curtis. Kingston. Ont.: Department of Industrial Relations, Queen's University, 1957, pp. 90.

Here is a special study of the procedures followed in the arbitration of union-management disputes in the manufacturing industries of Ontario. It has been carried out by an associate professor of Industrial Relations at Queen's University, in co-operation with the Labour Department-University Research Committee and after consulting such indispensable instruments as the sixvolume Labour Arbitration Cases published by the Central Ontario Industrial Relations Institute.

This small book deals with such topics as "The Nature of Arbitration", "The Provision for Arbitration in Collective Agreements", "Procedures Leading to the Appointment of the Arbitrator", "The Arbitration Hearing", and "The Arbitrator's Award".

The reader must be warned that, as the title suggests, this book describes arbitration procedures alone; it contains no discussion nor survey of arbitration awards in their substance.

Within the limits he has set for himself, the Author has done a useful and original work which should be of interest to all those who are interested in the processes of industrial arbitration in Canada, and more specifically in the Province of Ontario.

R. C. 